Allergo J Int (2017) 26:283

https://doi.org/10.1007/s40629-017-0038-7

CrossMark

\title{
Correction to: Abstracts of the 12th German Allergy Congress
}

\section{Wiesbaden, October 5-7, 2017}

\section{Marion Weber}

Published online: 25 October 2017

(C) Springer Medizin Verlag GmbH 2017

\section{Correction to:}

Allergo J Int 2017

https://doi.org/10.1007/s40629-017-0036-9

The original article has been corrected. Erroneously, in the online html article "abstract" was given as article title. 